\title{
Ectoparasites of dogs in home environments on the Caribbean slope of Costa Rica
}

\author{
Ectoparasitos de cães no ambiente doméstico da vertente Caribe, Costa Rica \\ Adriana Troyo $^{1 *}$; Ólger Calderón-Arguedas ${ }^{1}$; Gilbert Alvarado ${ }^{2,3,4}$; Luis E. Vargas-Castro ${ }^{4}$; Adrián Avendaño ${ }^{1}$ \\ ${ }^{1}$ Departamento de Parasitología, Centro de Investigación en Enfermedades Tropicales, Facultad de Microbiología, \\ Universidad de Costa Rica - UCR, San José, Costa Rica \\ ${ }^{2}$ Departamento de Patología, Escuela de Medicina Veterinaria, Universidad Nacional, Heredia, Costa Rica \\ ${ }^{3}$ Centro de Investigación en Estructuras Microscópicas, Universidad de Costa Rica - UCR, San José, Costa Rica \\ ${ }^{4}$ Escuela de Biología, Universidad de Costa Rica - UCR, San José, Costa Rica
}

Received July 21, 2011

Accepted March 21, 2012

\begin{abstract}
Reports on ectoparasites on dogs in Central America are scarce. The aim of this study was to identify flea, louse and tick species infesting dogs in home environments on the Caribbean slope of Costa Rica, and determine their frequency and coexistence. Ectoparasites were collected from dogs in 83 rural homes at five study sites. Specimens were identified and separated according to species. Fleas were the most common ectoparasite $(G=22,217, D F=8, p=0.004)$. Ctenocephalides felis and Pulex simulans were found in $83 \%$ and $55 \%$ of the homes with ectoparasites, respectively. Trichodectes canis (13\%), Heterodoxus spiniger (10\%), Rhipicephalus sanguineus (18\%), Rhipicephalus (Boophilus) microplus (5\%) and Amblyomma ovale (8\%) were also present. More than one species was collected in most cases (66\%), and the most common combination was $C$. felis and $P$. simulans (59\% of homes with fleas). The high frequency of $P$. simulans emphasizes the need for adequate identification. This was the first study involving different ectoparasites of dogs in Costa Rica, as well as the first report of $T$. canis in this country. The relative frequency and coexistence of these ectoparasites in the home environment may have implications for animal and human health.
\end{abstract}

Keywords: Domestic dogs, Pulex simulans, Ixodida, Siphonaptera, Phthiraptera, Costa Rica.

\section{Resumo}

Relatos de ectoparasitos em cães da América Central são escassos. O objetivo deste estudo foi identificar espécies de pulgas, piolhos e carrapatos que infestam os cáes no ambiente doméstico da vertente Caribe da Costa Rica, determinando sua frequência e coexistência. Foram coletados ectoparasitos de cáes em 83 casas rurais de cinco sítios do estudo. Os indivíduos foram separados e identificados. Os ectoparasitos mais comuns foram as pulgas $(\mathrm{G}=22.217$, $\mathrm{DF}=8$, $\mathrm{p}=0.004)$. Ctenocephalides felis e Pulex simulans foram observados em $83 \%$ e $55 \%$ das moradias com ectoparasitos, respectivamente. Da mesma forma também foram observados Trichodectes canis (13\%), Heterodoxus spiniger (10\%), Rhipicephalus sanguineus (18\%), Rhipicephalus (Boophilus) microplus (5\%) e Amblyomma ovale (8\%). Na maioria dos casos, mais de uma espécie foi achada (66\%), sendo que a combinação mais comum foi $C$. felis e $P$. simulans (59\% de moradias com pulgas). A frequência alta de $P$. simulans ressalta a necessidade de sua adequada identificação. Este é o primeiro estudo que envolve diferentes ectoparasitas de cáes na Costa Rica, da mesma forma, é o primeiro relato de T. canis no país. A frequência relativa e coexistência destes ectoparasitos no ambiente domiciliar poderiam ter implicaçóes na saúde animal e humana.

Palavras chave: Cães domésticos, Pulex simulans, Ixodida, Siphonaptera, Phthiraptera, Costa Rica.

\footnotetext{
${ }^{*}$ Corresponding author: Adriana Troyo

Departamento de Parasitología, Centro de Investigación en Enfermedades Tropicales, Facultad de Microbiología, Universidad de Costa Rica - UCR, Ciudad Universitaria Rodrigo Facio, CEP 11501, San José, Costa Rica

e-mail: adriana.troyo@ucr.ac.cr
} 
Fleas (Siphonaptera), lice (Pthiraptera) and ticks (Ixodida) have long been recognized as important groups of arthropods that infest mammals, including domestic dogs, Canis lupus familiaris (BOWMAN, 1995). The most common fleas on dogs are Ctenocephalides felis and Ctenocephalides canis, although Pulex irritans and Pulex simulans can frequently be encountered (DURDEN et al., 2005; BECK et al., 2006). The lice include the chewing lice Heterodoxus spiniger and Trichodectes canis, as well as the biting louse Linognathus setosus (GONZÁLEZ et al., 2004). Different tick species infest domestic dogs depending on the geographical area; however, one of the most widely distributed is Rhipicephalus sanguineus (DANTAS-TORRES, 2008). Although most of these ectoparasites are considered to be cosmopolitan, many species show differences in prevalence depending on the particular geographical area. For instance, C. canis is frequently found on dogs in European countries and in some areas of South America (GONZÁLEZ et al., 2004; XHAXHIU et al., 2009), although it can be rare in other countries. A similar scenario can be depicted for specific populations of other fleas, lice and ticks.

The presence of ectoparasites on a dog can have a negative impact on the animal's health. Fleas are usually associated with dermatitis and allergic reactions with varying degrees of severity (KOUTINAS et al., 1995). Fleas, ticks and sucking lice exhibit hematophagic behavior, and some species act as intermediate hosts and/or vectors of pathogens such as Ehrlichia spp., Anaplasma spp., Rickettsia spp., Borrelia spp., Bartonella spp., Babesia spp. and Dipylidium caninum (BOWMAN, 1995; GONZÁLEZ et al., 2004). Furthermore, many pathogens transmitted by fleas and ticks of dogs are considered to be zoonotic and may affect humans.

In Central America, knowledge of dog ectoparasites and their contact with humans is limited. Recent scientific papers about this particular topic are scarce, and those available for Costa Rica and most of Central America are restricted to new records or specific groups of ectoparasites (VARGAS; MÉNDEZ, 1987; ALVAREZ CALDERÓN et al., 2005; ÁLVAREZ et al., 2006). To our knowledge, there are no specific studies in Costa Rica on flea and louse populations in domestic dogs. This paper describes the species of fleas, lice and ticks of domestic dogs present in home environments on the Caribbean slope of Costa Rica. This provides useful evidence for the veterinary community in terms of the relative frequencies and coexistence of ectoparasites, as well as support for future studies aiming to make links to some of the potential pathogens transmitted to these species in this region.

Ectoparasites were collected from dogs between July 2008 and December 2010, as part of an ongoing project to detect Rickettsia spp. in areas of the Caribbean slope of Costa Rica where cases of spotted fevers have been documented (HUN-OPFER, 2008). This region is characterized by continuous wet (annual rainfall of 2,500 to $3,000 \mathrm{~mm}$ ) and warm (mean temperatures of $23-26^{\circ} \mathrm{C}$ ) conditions without distinct seasonality (IMN, 2009). Five sites were selected, specifically in the districts of Turrialba $\left(9^{\circ} 54^{\prime} \mathrm{N}\right.$,

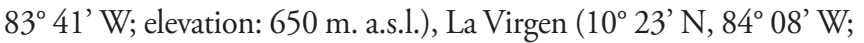
elevation: 190 m. a.s.1.), Limón (9 $59^{\prime} \mathrm{N}, 83^{\circ} 02^{\prime} \mathrm{W}$; elevation: 5 m. a.s.l.), Cahuita ( $9^{\circ} 44^{\prime} \mathrm{N}, 82^{\circ} 50^{\prime} \mathrm{W}$; elevation: $5 \mathrm{~m}$. a.s.l.), Guápiles ( $10^{\circ} 13^{\prime} \mathrm{N}, 83^{\circ} 47^{\prime} \mathrm{W}$; elevation: $260 \mathrm{~m}$. a.s.l.), Jiménez $\left(10^{\circ} 12^{\prime} \mathrm{N}, 83^{\circ} 44^{\prime} \mathrm{W}\right.$; elevation: $230 \mathrm{~m}$. a.s.l.) and Guácimo $\left(10^{\circ} 12^{\prime} \mathrm{N}, 83^{\circ} 41^{\prime} \mathrm{W}\right.$; elevation: $110 \mathrm{~m}$. a.s.l.). The urban centers of Guápiles, Jiménez and Guácimo (GP/J/GC) are less than $20 \mathrm{~km}$ distance from each other and were therefore considered to be the same study site.

Homes were selected using a non-probabilistic approach and mainly included households located in rural settings with nearby forested areas. In addition, they were at least $100 \mathrm{~m}$ from each other, had one or more dogs that were allowed to roam freely in and around the home, and presented any of the ectoparasites of interest on at least one dog. Considering that dogs in home environments are in close contact with each other and probably share the same ectoparasite species, the analysis was performed by pooling samples of one to three dogs from the same home instead of using samples from individual dogs. This reduced the errors attributable to lack of independence between dogs that share homes, as well as differences in total numbers of dogs per home.

Fleas, lice and ticks were collected using combs and tweezers during a period no longer than one man-hour per home, and were placed in $70 \%$ ethanol for transporting to the laboratory. The specimens were separated and grouped into batches according to species, collection site and specific household. They were identified by observing key characters, and some specimens were cleared in lactophenol and mounted in Hoyer's medium when this was required to confirm species identification (HOPKINS; ROTHSCHILD, 1953; SMIT, 1958; EMERSON; PRICE, 1975; BARROS-BATTESTI et al., 2006). Variations in frequency between different groups of ectoparasites were analyzed using a G-test. In addition, a chi-square test was used to determine whether the frequencies of flea species differed (SOKAL; ROHLF, 1994). An alpha value of 0.05 was used in all tests, and analyses were performed in $\mathrm{JMP}^{\circ} 7.0$ (SAS Institute, Inc.).

Ectoparasites were collected from a total of 83 rural homes. Fleas, lice and ticks were observed on dogs at the five study sites (Table 1). Overall, fleas were the most frequent ectoparasite found $(\mathrm{G}=22,217, \mathrm{DF}=8, \mathrm{p}=0.004)$. Ctenocephalides felis was present in $83 \%$ of the households, and it was the most common ectoparasite in the home environments of all of the sites evaluated. Pulex simulans was identified in $55 \%$ of the homes with ectoparasites, and it was also widespread at the study sites. The brown dog tick, $R$. sanguineus, was found in $18 \%$ of the homes, while Amblyomma ovale (8\%) and Rhipicephalus (Boophilus) microplus (5\%) were less frequent. The chewing lice, T. canis and $H$. spiniger, were present on dogs from $13 \%$ and $10 \%$ of the homes, respectively.

Only 28 (34\%) of the homes had a single species present, and it was usually $C$. felis. Two species were present simultaneously in 36 (43\%) of the households, and C. felis plus $P$. simulans was the most common combination. Sixteen homes (23\%) had three or more ectoparasites present, and the combination of $C$. felis, $P$. simulans and $H$. spiniger was the most frequent.

Coexistence of $C$. felis and $P$. simulans was common at all sites (Figure 1). Out of 69 homes in which fleas were found on dogs, 41 (59\%) had both species, while 28 (40\%) only had C. felis and five $(7 \%)$ only had $P$. simulans. Considering the frequency of each species observed in homes with fleas, the likelihoods of finding $C$. felis versus finding $P$. simulans were not significantly different $\left(\chi^{2}=1.852, \mathrm{DF}=4, \mathrm{p}=0.763\right)$.

Most of the ectoparasites that were found on the Caribbean slope of Costa Rica have also been reported elsewhere in Central America 
Table 1. Frequencies of homes (\%) with domestic dogs infested by ectoparasites according to species and study site on the Caribbean slope of Costa Rica.

\begin{tabular}{|c|c|c|c|c|c|c|}
\hline \multirow[b]{2}{*}{ Species of ectoparasites } & \multicolumn{5}{|c|}{ Study site } & \multirow[b]{2}{*}{$\begin{array}{c}\text { Total } \\
\mathrm{n}=83\end{array}$} \\
\hline & $\begin{array}{c}\text { Cahuita } \\
\mathrm{n}=14\end{array}$ & $\begin{array}{c}\mathrm{GP} / \mathrm{J} / \mathrm{GC}^{*} \\
\mathrm{n}=\mathbf{2 5}\end{array}$ & $\begin{array}{c}\text { Sarapiquí } \\
\mathrm{n}=12\end{array}$ & $\begin{array}{l}\text { Limón } \\
\mathrm{n}=15\end{array}$ & $\begin{array}{c}\text { Turrialba } \\
\mathbf{n}=17\end{array}$ & \\
\hline \multicolumn{7}{|l|}{ Siphonaptera } \\
\hline Pulex simulans & $5(36)$ & $10(40)$ & $8(67)$ & $11(73)$ & $12(71)$ & $46(55)$ \\
\hline \multicolumn{7}{|l|}{ Phthiraptera } \\
\hline \multicolumn{7}{|l|}{ Ixodida } \\
\hline Rhipicephalus sanguineus & $2(14)$ & $7(28)$ & $2(17)$ & $1(7)$ & $3(18)$ & $15(18)$ \\
\hline Amblyomma ovale & $5(36)$ & $2(8)$ & $0(0)$ & $0(0)$ & $0(0)$ & $7(8)$ \\
\hline Rhipicephalus (B.) microplus & $0(0)$ & $2(8)$ & $1(8)$ & $0(0)$ & $1(6)$ & $4(5)$ \\
\hline
\end{tabular}

*GP/J/GC: Guápiles/Jiménez/Guácimo.

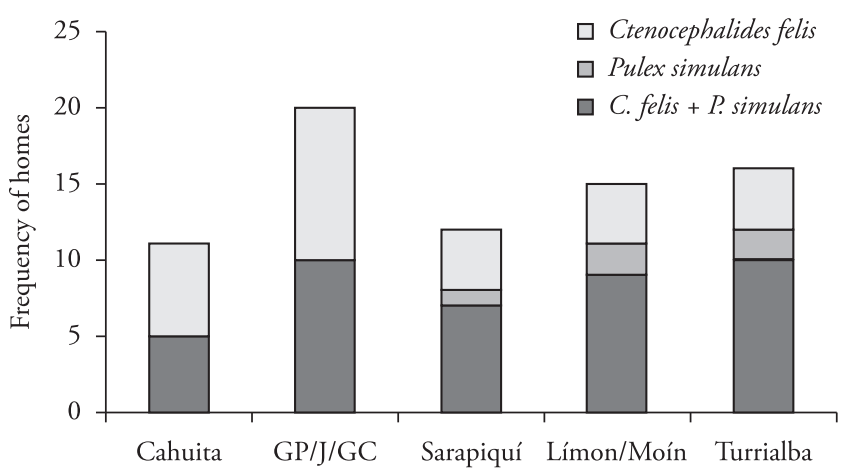

Figure 1. Frequencies of homes with domestic dogs infested by fleas in which only Ctenocephalides felis, only Pulex simulans, or both of these flea species were observed, according to study site on the Caribbean slope of Costa Rica. Legend at foot of figure: GP/J/GC: Guápiles/Jiménez/Guácimo.

(WOKE, 1947; WENZEL; TRIPTON, 1966). In agreement with the present report, $C$. felis has usually been the most common ectoparasite of dogs reported in Latin America, although C. canis has been described in some areas as the predominant species in rural environments (ALCAÍNO et al., 2002; GONZÁLEZ et al., 2004).

This is the first report from Costa Rica concerning the frequency of $P$. simulans. According to recent studies, the prevalence of $P$. simulans on rural dogs in Guatemala was $6.8 \%$ (ESCOBAR et al., 2011), while this species was only found in three out of 57 communities in Panama and at elevations greater than 1100 m.s.l. (BERMÚDEZ; MIRANDA, 2011). In contrast, $P$. simulans was present at all five sites evaluated in the present study, and it occurred very commonly in home environments. The presence of this flea in Guatemala, in Panama and at different sites and elevations in Costa Rica indicate that $P$. simulans has widespread distribution on dogs in Central America.

Previous listings of dog fleas in Central America include P. irritans (WOKE, 1947). As has been hypothesized in previous reports, it is highly possible that most of these findings correspond to $P$. simulans, which may not have been correctly identified or considered to be a separate species at the time (ECKERLIN, 2005;
ESCOBAR et al., 2011). In spite of the growing information regarding $P$. simulans from other areas of North and South America (DITTMAR et al., 2003; DURDEN et al., 2005), there are documents that inform that $P$. irritans is a common species on dogs in Colombia and Chile (ALCAÍNO et al., 2002; CAÑÓN-FRANCO; PÉREZ-BEDOYA, 2010). This new evidence from Costa Rica emphasizes the importance of accurate identification and differentiation of these two species.

Similar to the situation of $P$. simulans, the relative frequency of chewing lice had not been reported previously in any area of Costa Rica. Heterodoxus spiniger was documented in Costa Rica for the first time in 1987 (VARGAS; MÉNDEZ, 1987), and although this is its first official report in the scientific literature, observations of $T$. canis by veterinarians are known to occur. Moreover, it was surprising to find considerable occurrence of these lice, and in coexistence with other ectoparasites, on rural domestic dogs.

Unlike some reports of low concurrent infestation on dogs (CHEE et al., 2008), coexistence of more than one species in home environments was unexceptional in this area, and one or more of these arthropods may be associated with health problems in dogs. Although Ctenocephalides is an important cause of flea allergy (KOUTINAS et al., 1995), the immunogenic potential of $P$. simulans is unknown and may be important given its coexistence with $C$. felis in this region. In addition, the widespread presence of chewing lice can affect the animals by causing further skin irritation and stress (VARGAS; MÉNDEZ, 1987).

Rhipicephalus sanguineus was the most common tick detected, which agrees with previous reports from Costa Rica and elsewhere (ÁLVAREZ et al., 2006; DANTAS-TORRES, 2008). In some countries, ticks have been found to be more frequent on dogs than fleas, and prevalences close to $80 \%$ have been documented (NUCHJANGREED; SOMPRASONG, 2007). The other tick species observed at the sites of the present study, $R$. (B.) microplus and $A$. ovale, have also been reported in different areas of Central and South America (ÁLVAREZ et al., 2006; BERMÚDEZ; MIRANDA, 2011; RODRIGUES et al., 2008). Amblyomma ovale infests carnivores and can be common on dogs, while $R$. (B.) microplus is more associated with cattle and is only occasionally found on dogs. 
The flea and tick species detected in this study may also be associated with transmission of animal and human pathogens such as Ehrlichia canis and Rickettsia felis, which have already been identified respectively in $R$. sanguineus and $C$. felis in Costa Rica (ROMERO et al., 2011; HUN et al., 2011). The presence of these and other dog ectoparasites in home environments may suggest that there is high potential for transmission of pathogens. The relative frequencies and coexistence of ticks with fleas and lice, as well as their proximity to human dwellings demonstrate possible implications for animal and human health in a region where information about ectoparasites of domestic animals is scarce.

\section{Acknowledgements}

The authors thank Iván Coronado, Julio Rojas, Greivin Rodríguez and Carlos Fernández for technical support during field work; Alexander Genoy-Puerto, Angélica Sánchez-Sarmiento and Camila Boniche for Portuguese translation; and Sergio Bermúdez and the Publications Workshop (INISA) for comments on the manuscript. This research was supported in part by NeTropica grant 9-N-2008 and Universidad de Costa Rica project 803-A8-127.

\section{References}

Alcaíno HA, Gorman TR, Alcaíno R. Flea species from dogs in three cities of Chile. Vet Parasitol2002; 105(3): 261-265. http://dx.doi.org/10.1016/ S0304-4017(01)00626-4

Alvarez Calderón V, Hernández Fonseca V, Hernández Gamboa J. Catálogo de garrapatas suaves (Acari: Argasidae) y duras (Acari: Ixodidae) de Costa Rica. Brenesia 2005; 63-64: 81-88.

Álvarez V, Bonilla R, Cascante J. Casuística de Rhipicephalus sanguineus y Amblyomma spp. (Acari: Ixodidae) en perros atendidos en clínicas veterinarias ubicadas en los cantones de Escazú, Santa Ana y Mora. Cienc Vet 2006; 24(1): 9-18.

Barros-Battesti DM, Arzua M, Bechara GH. Carrapatos de importância médico-veterinária da regiâo neotropical: um guia ilustrado para identificação de espécies. São Paulo: Vox/ICTTD-3/Butantan; 2006.

Beck W, Boch K, Mackensen H, Wiegand B, Pfister K. Qualitative and quantitative observations on the flea population dynamics of dogs and cats in several areas of Germany. Vet Parasitol 2006; 137(1-2): 130-136. PMid:16442233. http://dx.doi.org/10.1016/j.vetpar.2005.12.021

Bermúdez CS, Miranda CR. Distribution of ectoparasites of Canis lupus familiaris L. (Carnivora: Canidae) from Panama. Rev MVZ Córdoba 2011; 16(1): 2274-2282.

Bowman DD. Georgi's Parasitology for Veterinarians. 6th ed. Philadelphia: W.B. Saunders Company; 1995.

Cañón-Franco WA, Pérez-Bedoya JL. Siphonaptera (Pulicidae) in dogs and cats of Colombia: Clinical and epidemiological aspects. Vet Parasitol 2010; 173(3-4): 353-357. PMid:20728994. http://dx.doi. org/10.1016/j.vetpar.2010.07.014

Chee JH, Kwon JK, Cho HS, Cho KO, Lee YJ, Abd El-Aty AM, et al. A survey of ectoparasite infestations in stray dogs of Gwang-ju City, Republic of Korea. Korean J Parasitol 2008; 46(1): 23-27. PMid:18344673 PMCid:2526298. http://dx.doi.org/10.3347/kjp.2008.46.1.23
Dantas-Torres F. The brown dog tick, Rhipicephalus sanguineus (Latreille, 1806) (Acari: Ixodidae): from taxonomy to control. Vet Parasitol 2008; 152(3-4): 173-185. PMid:18280045. http://dx.doi. org/10.1016/j.vetpar.2007.12.030

Dittmar K, Mamat U, Whiting M, Goldmann T, Reinhard K, Guillen S. Techniques of DNA-studies on prehispanic ectoparasites (Pulex sp., Pulicidae, Siphonaptera) from Animal mummies of the Chiribaya culture, southern Peru. Mem Inst Oswaldo Cruz 2003; 98 (suppl. 1): 53-58. http:// dx.doi.org/10.1590/S0074-02762003000900010

Durden LA, Judy TN, Martin JE, Spedding LS. Fleas parasitizing domestic dogs in Georgia, USA: species composition and seasonal abundance. Vet Parasitol 2005; 130(1-2): 157-162. PMid:15893082. http://dx.doi.org/10.1016/j.vetpar.2005.03.016

Eckerlin RP. Fleas (Siphonaptera) of the Yucatan Peninsula (Campeche, Quintana Roo, and Yucatan), Mexico. Caribbean J Sci 2005; 41(1): 152-157.

Emerson KC, Price RD. Mallophaga of Venezuelan mammals. Brigham Young University Sci Bull 1975; 20(3): 1-77.

Escobar LE, Álvarez D, Villatoro FJ, Morán D, Estévez A. Two new flea records from Guatemala: Pulex simulans and Echidnophaga gallinacea (Siphonaptera: Pulicidae), and their host-parasite relationship.J Parasitol Vector Biol 2011; 3(3): 40-43.

González A, Castro DDC, González S. Ectoparasitic species from Canis familiaris (Linné) in Buenos Aires province, Argentina. Vet Parasitol 2004; 120(1-2): 123-129. PMid:15019149. http://dx.doi.org/10.1016/j. vetpar.2003.12.001

Hopkins GHE, Rothschild M. An illustrated catalogue of the Rothschild collection of fleas (Siphonaptera) in the British Museum (Natural History) with keys and short descriptions for the identification of families, genera, species and subspecies. Cambridge: University Press; 1953. vol. 1: Tungidae and Pulicidae.

Hun L, Troyo A, Taylor L, Barbieri AM, Labruna MB. First report of the isolation and molecular characterization of Rickettsia amblyommii and Rickettsia felis in Central America. Vector-Borne Zoonotic Dis 2011; 11(10): 1395-1397. PMid:21612539. http://dx.doi.org/10.1089/ vbz.2011.0641

Hun-Opfer L. Las fiebres manchadas y su importancia en Costa Rica. Acta Méd Costarric, 2008; 50(2): 77-86.

Instituto Meteorológico Nacional - IMN. Clima en Costa Rica, Vertiente del Caribe [on line]. 2009 [cited 2012 Mar 21]. Available from: www. imn.ac.cr/educacion/climacr/vertiente_caribe.html.

Koutinas AF, Papazahariadou MG, Rallis TS, Tzivara NH, Himonas CA. Flea species from dogs and cats in northern Greece: environmental and clinical implications. Vet Parasitol 1995; 58(1-2): 109-115. http:// dx.doi.org/10.1016/0304-4017(94)00706-I

Nuchjangreed C, Somprasong W. Ectoparasite species found on domestic dogs from Pattaya district, Chon Buri province, Thailand. Southeast Asian J Trop Med Public Health 2007; 38 (suppl. 1): 203-207.

Rodrigues DF, Daemon E, Rodrigues AFS. Caracterização da população de ectoparasitos em cáes de núcleos de expansão urbana de Juiz de Fora, Minas Gerais, Brasil. Rev Bras Parasitol Vet 2008; 17(4): 185-188. PMid:19265575.

Romero LE, Meneses AI, Salazar L, Jiménez M, Romero JJ, Aguilar DM, et al. First isolation and molecular characterization of Ehrlichia canis in Costa Rica, Central America. Res Vet Sci 2011; 91(1): 95-97. PMid:20723954. http://dx.doi.org/10.1016/j.rvsc.2010.07.021 
Smit FGAM. A preliminary note on the occurence of Pulex irritans L. and Pulex simulans Baker in North America. J Parasitol 1958; 44(5): 523-526. PMid:13576273. http://dx.doi.org/10.2307/3274425

Sokal R, Rohlf F. Biometry: The Principles and Practices of Statistics in Biological Research. 3rd ed. New York: W.H. Freeman; 1994.

Vargas M, Méndez CR. Hallazgo de Heterodoxus spiniger (Enderlein, 1909) (Mallophaga: Boopidae) en Costa Rica. Cienc Vet 1987; 9(2-3): 133-136.
Wenzel RL, Tripton VJ. Ectoparasites of Panama. Chicago: Field Museum of Natural History; 1966.

Woke PA. Arthropods of sanitary importance in the republic of Nicaragua, Central America. Am J Trop Med Hyg 1947; s1-27(3): 357-375.

Xhaxhiu D, Kusi I, Rapti D, Visser M, Knaus M, Lindner T, et al. Ectoparasites of dogs and cats in Albania. Parasitol Res 2009; 105(6): 1577-1587. PMid:19690887. http://dx.doi.org/10.1007/ s00436-009-1591-x 